\title{
Determination of water quality, trace elements contamination in Oreochomis niloticus and Clarias gariepinus reared in 2 types of ponds and health risk assessment in Cameroon
}

\section{Isabelle Sandrine Bouelet Ntsama ( $\sim$ ibouelet@yahoo.fr)}

Advanced training teacher college for technical education

\section{Betrand Ayuk Tambe}

Centre for Food and Nutrition research

Christine Fernande Nyangono Biyegue

Advanced Teacher training college for technical education, University of Douala

\section{Guy Pouokam}

Laboratory of food safety, Biotechnology Center, University of Yaoundé

Hélène Claudia Mentho

Advanced teacher training college for technical education, University of Douala

Julie Judith Tsafack Takadong

Centre for food and nutrition research, IMPM, Yaoundé

\section{Gabriel Medoua Nama}

Centre for food and nutrition research, IMPM, Yaoundé

\section{Jordi Serratosa}

Universitat Autonoma de Barcelona

\section{Germain Kansci}

Department of Biochemistry, Laboratory of food science and metabolism, Faculty of Sciences, University of Yaoundé

\section{Data Article}

Keywords: Fish farming, Heavy metals, concrete ponds, earthen ponds, target hazard quotient, Cameroon

Posted Date: February 12th, 2020

DOI: https://doi.org/10.21203/rs.2.23261/v1

License: (c) (i) This work is licensed under a Creative Commons Attribution 4.0 International License. Read Full License 


\section{Abstract}

Background: Fish farming in Cameroon is growing very rapidly and fish available in the markets is mostly coming from fish farms, but domestic fish production is still low to meet demand. Intensification of production could lead to the occurrence of various types of contaminants that can affect the sanitary quality of farmed fish and consumer health. This study aimed to assess the quality of farmed fish collected in fish farms located in four regions of Cameroon (Center, South, West, Littoral).

Results: Concentrations of arsenic, cadmium, lead, chromium, cobalt, and nickel were determined in pond water and muscles of Oreochromis niloticus and Clarias gariepinus raised in concrete and earthen ponds to evaluate health risk for consumers. Trace elements were determined using Inductively Coupled Plasma Optical Emission spectrometry (ICP-OES). Heavy metals in water for concrete and earthen ponds shows there are no significant differences $(p<0.05)$ between the rearing systems except for cobalt and nickel. Heavy metals concentrations in water were lower when compared to the WHO recommended limits except for cadmium in all the ponds. For concrete ponds, heavy metal concentrations decreased in water in the sequence of $\mathrm{Cd}>\mathrm{As}>\mathrm{Co}>\mathrm{Ni}>\mathrm{Cr}>\mathrm{Pb}$. For earthen ponds the concentrations decreased as $\mathrm{Cd}>$ $\mathrm{Co}>\mathrm{As}>\mathrm{Ni}>\mathrm{Cr}>\mathrm{Pb}$.

Conclusion: Concentrations recorded in the muscles of the 2 species were above the safety limits recommended by FAO/WHO. The target hazard quotient of As was highest compared to other metals and higher than the acceptable limits according to US Environmental Protection Agency guidelines in all fish species. the level of each investigated metal, highlighted a very low health risk for consumers.

\section{Introduction}

During recent decades the global consumption of fish has increased due to growing population and rapid urbanization (Wim et al. 2007). Furthermore, fish is a major part of the human diet because it provides a healthy, low cholesterol source of protein and other nutrients including omega 3 fatty acid that reduce cholesterol levels and the incidence of heart disease (Ruxton et al. 2004 ). It has been predicted that fish consumption in developing countries will increase by 57 percent, from 62.7 million metric tons in 1997 to 98.6 million in 2020 (Delgado et al. 2003). Over the last 20 years, stocks of many fish species are in decline attributed to illegal and over-fishing. Therefore fish farming appears to be a great solution to the massive demand for animal protein. Many production system exits for fish farming, in Cameroon it's mainly earthen ponds and concrete ponds that are use to cultivate fishes. It's well known that aquatic organisms are characterized by accumulation of many harmful elements in the body amongst them heavy metals. The water used for fish farming contains very high concentrations of heavy metals which can affect adversely the quality of the final product cultivated fish and consumer health (Staykov 2001). The accumulation of heavy metals in fish mainly depends on their concentrations in food and water, in this aspect the production system has an essential role. According to many authors high concentrations of heavy metals in water may have devastating effect on the ecological balance in the environment and 
in the diversity of aquatic organisms (Farombi et al. 2007). The consequence of this is a large loss of fish production on fish farms.

The presence of contaminating heavy metals in freshwater ponds at concentrations above natural loads has become a growing concern. Recent studies have investigated for instance fish contamination by lead, cadmium and mercury which are very toxic (Zaza et al. 2015; Zheng Zhang et al. 2007; Stancheva et al. 2013).Various studies in different countries reported the contamination of different farmed fish species with a different type of pollutants, trace metals are of particular concern, due to their potential toxic effect and ability to bioaccumulate in aquatic ecosystems (Vutukuru 2005; Dirilgen 2001; Voegborlo et al. 1999; Canli et al. 1998). In many developing countries, metals pollution problems in the fish farming sites were serious as reflected by high metal concentration recorded in Malawi (Puchase and Jamu 2009), Zimbabwe (Teta, Ncube and Naik 2017). Other studies conducted in india and Nigeria (Nath and Bhoumik 2013; Ibemenuga et al. 2013; Kumari et al. 2017) indicated high level of cadmium, arsenic and lead in water and fish tissues. Some regulatory agencies have categorized them as pollutants of high importance (US Enviromental Protection Agency 2006). Trace metals occur naturally in the environment and are present in low concentrations in freshwater (VanLoon and Duffy 2011). Rapid population growth, increased urbanization, the expansion of industrial activities, the exploration and exploitation of natural resources, the extension of irrigation and the spread of modern agricultural practices should be blamed for the occurrence of heavy metals. Increases use of fertilizers, which contain metals could also result in high concentration of trace metal in fish ponds. Fishes have been widely used as bio-indicators of pollution by metals in aquatic system because they occupy different trophic levels (Burger et al. 2002).

Cameroon like many other countries, is facing severe problem of freshwater pollution as almost $99 \%$ of the industrial waste water is discharged into streams and rivers without any treatment (Khan et al. 2012) which is undesirably distressing natural resources of the country (Rauf et al. 2009). Domestic fish production is still low to meet demand. Fish farming appears as a solution to fill this gap. These last years there is a tendency to increase the number of fish farm and intensify the production to fill the gap. Intensification of production could lead to the occurrence of various types of contaminants that can affect the quality of farmed fish and consumer health. Few studies exist concerning fish ponds contamination by heavy metals in Cameroon. The studies have mainly concerned wild fish species commonly found in rivers and lake. For instance, Fonge et al. 2011 assessed the contamination of Dibamba river and Arius heudelottii by $\mathrm{Co}, \mathrm{Cd}, \mathrm{Pb}, \mathrm{Fe}, \mathrm{Cu}$. Another study reported the contamination of heavy metals ( $\mathrm{Cr}, \mathrm{Cd}, \mathrm{Hg}, \mathrm{Pb}$ and $\mathrm{Zn}$ ) in fish, mud and water from two urban lakes in Yaoundé (Demanou and Brumett 2010). Nkwelle et al. (2012) works on the determination of water quality, and trace metals in endemic Sarotherodon linellii, Pungu maclareni and Clarias maclareni, in crater lake Barombi Mbo in the south west region of Cameroon. There is no report on water quality in fishponds and heavy metals contamination in farmed species; furthermore no data exist on the potential health risk related to the consumption of contaminated fishes with respect to the rearing system. There is a need to investigate on the influence of intensification of production system on farmed fish in order to limit the risks and to improve the quality of water and final product. O. niloticus and C. gariepinus are amongst the most common fishes reared and consumed in Cameroon. Therefore metal accumulation in these fish species 
presents serious public health. The fact that metals accumulate in the environment necessitates their continuous monitoring and assessment in respect of both ecological and human health impact. The purpose of the present study was to determine the level of heavy metal contamination ( $\mathrm{As}, \mathrm{Cd}, \mathrm{Cr}, \mathrm{Pb}, \mathrm{Co}$, $\mathrm{Ni}$ ) in water, and muscle tissues of $\mathrm{O}$. niloticus and $\mathrm{C}$.gariepinus reared in earthen and concrete ponds to assess the ecological and public health risks and to identify possible sources of the metals for future remedial action. Additionally, to compare the two systems with regards to heavy metals contamination and health risks.

\section{Material And Methods}

\section{Study area}

The study was conducted in four regions of Cameroon: the center, the south, the littoral and the west regions as shown in Fig. 1. The different regions were selected as they represent a high potential for fish farming due to favourable resources and climatic conditions. The center region covers $69.000 \mathrm{~km}^{2}$ and is composed of rolling hills on a vast plain with a mean altitude of 700-800 m, with lowered mounds. The climate has two wet seasons. The population density is low, with about 36 inhabitants $/ \mathrm{km}^{2}$ (BUCREP 2010; NIS 2006). The south region covers an area of $47.110 \mathrm{~km}^{2}$, with a population of about 534.900 inhabitants and a density of 13.4 inhabitants per $\mathrm{km}^{2}$ (NIS 2006). The Littoral region is covering an area of $20.239 \mathrm{~km}^{2}$ and housing more than 2.202 .340 inhabitants. The west region covers $13.872 \mathrm{~km}^{2}$ and is mountainous, marked by highlands with a mean altitude of $1600 \mathrm{~m}$ and narrow valleys with catchments separating them. The climate has a unimodal wet season. The population density is relatively high, with about 143 inhabitants $/ \mathrm{km}^{2}$ (BUCREP 2010). The population density is 124 inhabitants per km².

\section{Sample collection}

The samples were collected between April and August 2017, a total of 70 fish samples (35 samples of 0 . niloticus and 35 of C.gariepinus) and 35 water samples were randomly collected in 14 ponds respectively 8 earthen ponds (plate 1) and 6 concrete ponds (plate 2). The pond sizes varies between 200 and $500 \mathrm{~m}^{2}$, each pond was sampled twice directly from fish farmers based in four regions of Cameroon as mentioned in table 1 . These regions were selected according to their importance in farmed fish production in the country. They have the largest proportion of fish farms in Cameroon. 
Table 1: Number of fish and pond samples per region

\begin{tabular}{cccclccc}
\hline Region & Town & Fish farms & $\begin{array}{c}\text { Production } \\
\text { system }\end{array}$ & Pond type & Water(n) & $\begin{array}{c}\text { Fish } \\
\text { (n) }\end{array}$ & $\begin{array}{c}\text { Number of ponds } \\
\text { sampled }\end{array}$ \\
\hline Centre & Yaoundé & Etokoss & Extensive & Earthen & 5 & 10 & 2 \\
- & - & odja & $\begin{array}{c}\text { Semi } \\
\text { intensive }\end{array}$ & Concrete & 5 & 10 & 2 \\
- & Mbalmayo & Fokou & $\begin{array}{c}\text { Semi } \\
\text { intensive }\end{array}$ & Concrete & 5 & 10 & 2 \\
- & Mfou & Bindo & Extensive & Earthen & 5 & 10 & 2 \\
\hline Littoral & Douala & Agroworld & $\begin{array}{c}\text { Semi } \\
\text { intensive }\end{array}$ & Concrete & 5 & 10 & 2 \\
\hline Sud & Sangmelima & Mimbo & Extensive & Earthen & 5 & 10 & 2 \\
\hline Ouest & Dschang & Fokoué & Extensive & Earthen & 5 & 10 & 2 \\
\hline
\end{tabular}

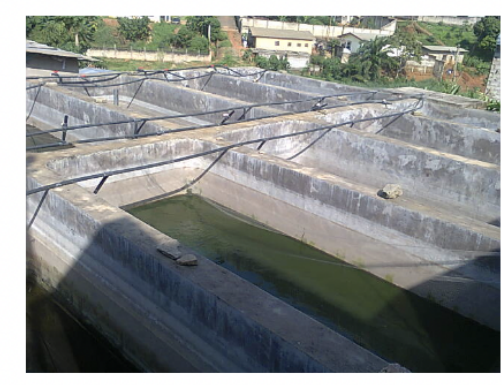

Plate 1 : Concrete fish ponds

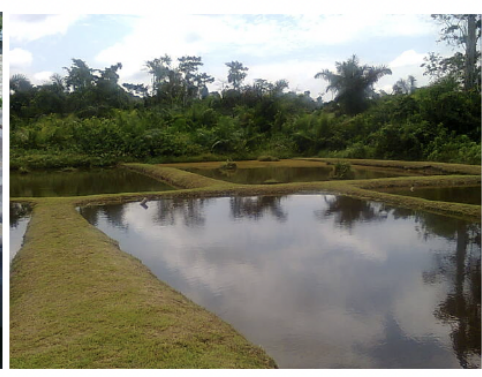

Plate 2: Earthen fish ponds

\section{- Water}

Triplicate 0.5 litre water samples from concrete and earthen were collected from fish farmers in each region, in different locations and depths of the ponds to obtain both representative and reproducible samples. Low-density plastic bottles were rinsed thrice with ambient water prior to sampling. One representative 1.5 litres composite for each fish pond was then obtained. For trace metals analysis samples were stored in acid-washed low density polyethylene bottles. Raw water samples were further transported in icebox to laboratory and were filtered through pre-cleaned cellulose acetate membrane filter paper $(0.45 \mathrm{~mm})$ and kept cold prior to trace metal analysis.

\section{- Fish}

Fish were collected to obtain information on the bioaccumulation of trace metals in fish pond area. Two species Clarias gariepinus and Oreochromis niloticus were chosen because they are amongst the farmed species mostly reared and consumed in the four regions. High consumption of these species was attributed to the fleshy nature and sweet taste. 70 fish samples, 5 each of $C$. gariepinus and 0 . niloticus were procured in seven fish farms located in each region. $C$. gariepinus samples have a mean weigth of $200 \pm 47.68 \mathrm{~g}$ and mean length of $20 \pm 1.5 \mathrm{~cm}$. O. niloticus have a mean weigth of $130 \pm 18 \mathrm{~g}$ and mean length of $16 \pm 1.45 \mathrm{~cm}$. These fish species were put in sterile polythene bags and taken in icebox to the 
laboratory where they were washed with running tap water to remove dirt. All the fish samples were then separately stored inside deep freezer at about $-4{ }^{\circ} \mathrm{C}$ and were allowed to thaw, scales were removed and washed with tap water before dissected with sterile scissors to remove gills, operculum, vertebrae, heart, muscles and kidney. Only the muscles tissue were transferred into sterile sample bottles, labeled and kept for digestion and analysis of heavy metals.

\section{Sample preparation and analysis}

\section{Determination of physico-chemical parameters}

The physico-chemical parameters of the water, including the temperature, $\mathrm{pH}$, electrical conductivity (EC), and total dissolved solids (TDS) were determined and analysed, Temperature was measured with glass mercury thermometer, conductivity was measured using Hanna Potable conductivity meter, pH was measured using a digital $\mathrm{pH}$ metre and total solids, dissolved solids and suspended solids was measured using gravimetric methods.

\section{Digestion of samples}

Fish samples were dried in an oven at $80-85^{\circ} \mathrm{C}$ overnight. The samples were removed from the oven, allowed to cool, and ground in a clean mortar and pestle. Approximately, $0.5 \mathrm{~g}$ of each sample was placed in a teflon microwave digestion bomb with $10 \mathrm{~mL}$ of concentrated HNO3. The samples were allowed to ramp to $180^{\circ} \mathrm{C}$ for $5 \mathrm{~min}$, digest at $180^{\circ} \mathrm{C}$ for $9.5 \mathrm{~min}$, and cool down for $5 \mathrm{~min}$ in a MARS 5 microwave digestion system (CEM, Matthews, NC). The samples were then transferred to clean volumetric flasks, and diluted with $\mathrm{H}_{2} \mathrm{O}$ to $10 \mathrm{~mL}$. The samples were stored at $5{ }^{\circ} \mathrm{C}$ until ready for analysis of metals.

An aliquot of $1 \mathrm{~L}$ water sample was digested with $5 \mathrm{~mL}$ concentrated nitric acid to a final volume of about $25 \mathrm{~mL}$. The digest was left to cool. It was then filtered into $50 \mathrm{~mL}$ volumetric flask and diluted to $50 \mathrm{~mL}$ mark with distilled water.

\section{Trace elements determination}

The digested sample was then filtered through Millipore membrane filter of $0.45 \mu \mathrm{m}$ (Type HV) and diluted up to $25 \mathrm{ml}$ by addition of distilled water. This filtrate of each fish sample was then processed for analysis of fish muscle content of arsenic (As), cadmium (Cd), chromium (Cr), cobalt (Co), lead (Pb), and nickel (Ni), were using Inductively Coupled Plasma (Perkin Elmer, Model: Optima7000 DV ICP-OES) following the Standard Methods (AOAC, 2012). Detection limits for $\mathrm{Cu}, \mathrm{Pb}, \mathrm{Cr}$ and $\mathrm{Cd}$ were $0.01 \mathrm{ppm}$. High purity metal standards were used for instrument calibration and also for accuracy checks after analysing every five samples. Metal levels in fish tissues were expressed as $\mathrm{mg} \mathrm{kg}^{-1} \mathrm{dry}$ weight, while metal levels in water were expressed as $\mathrm{mg} \mathrm{I}^{-1}(\mathrm{ppm})$. The wavelengths used for the detection and measurement of the trace elements are $193,696 \mathrm{~nm} ; 228,802 \mathrm{~nm} ; 267,716 \mathrm{~nm} ; 228,616 \mathrm{~nm} ; 220,353 \mathrm{~nm} ; 231,604 \mathrm{~nm}$ 
respectively. The levels of metal contamination of water in relation to fish were expressed as bioconcentration factor (BCF) according to the methods of Lau et al. (1998) calculated as:

$$
\text { BCF fish }=\frac{\text { Cfish }}{\text { Cwater }}
$$

where, $C$ fish is the mean concentration of the heavy metal in muscle of fish, $C$ water is the mean concentration of the metals in water and BCF fish is the bioconcentration factor of the metals in the fish.

\section{Health risk assessment}

\section{Target hazard quotient (THQ)}

The target hazard quotient (THQ) is an estimate of the risk level (non-carcinogenic) due to pollutant exposure. To estimate the human health risk from consuming metal-contaminated fish, the target hazard quotient (THQ) was calculated as per United States Environmental Protection Agency (USEPA) Region III Risk-Based Concentration. The method of estimating estimated daily intake (EDI) was provided by the US-EPA Region III risk based concentration table (US EPA, 2009) and Wang, Sato, Xing, and Tao (2005). EDI of each toxic metal was calculated using the Equation:

\section{$\left(E_{F} \times E D \times F I R \times C_{f} \times C\right) /\left(B W \times T_{A}\right)$}

where $E_{\mathrm{F}}$ is the exposure frequency (365 days/year); $E D$ is the exposure duration, equivalent to average lifetime, 59 years for Cameroonian population WHO (2017); FR is the fresh food ingestion rate (g/person/day), which was considered to be 42g/person/day for fish (Ali \& Hau, 2001); Cf is the conversion factor $(0.208)$ for fresh weight $(F W)$ to dry weight $(D W), C m$ is the heavy metal concentration in foodstuffs ( $\mu \mathrm{g} / \mathrm{kg} \mathrm{FW}$ ); BW is the average body weight (average adult body weight was considered to be $75 \mathrm{~kg}$ ) and $T A$ is the average exposure time for non-carcinogens (equal to $E_{\mathrm{F}} . E D$ ) (Saha \& Zaman, 2012). Health risk of consumers due to intake of metal in fish was assessed by using THQ in accordance with US-EPA Region III risk-based concentration table (US EPA, 2009) and Bortey-Sam et al. (2015). If THQ is less than 1 then the exposed population is unlikely to experience adverse effects; whereas THQ greater than 1 indicates a likelihood of non-carcinogenic effects, with an increasing probability as the value increase (Wang et al., 2005). THQ was calculated using the Equation

$T H Q=\frac{\left(M_{c} \times \mathrm{IR} \times 10^{-3} \times \mathrm{EF} \times \mathrm{ED}\right)}{(R f D \times B W \times A T n)}$

\section{Statistical analyses}

The results obtained were subjected to statistical evaluation. The concentration of trace metals in water and tissue samples were reported as the average means \pm standard deviation. From the normality test, the variables (metals in water and fish tissues) were not normally distributed. Consequently, a non 
parametric test Kruskal Wallis was used to examine differences in mean values among the two species and rearing systems with significance at $p<0.05$, using statistical package $\mathrm{R}$.

\section{Results And Discussion}

\section{Physicochemical parameters of pond waters and concentrations of toxic metal in water}

Physicochemical parameters (temperature, $\mathrm{pH}$, conductivity, total dissolved solids) and concentration of toxic metals of the pond waters are shown in Table 2. There were no significant differences in the physico-chemical characteristics of the water from earthen and concrete, only for TDS and conductivity $(p<0.05)$.

Table 2: Physicochemical parameters and concentration of trace elements (As, Cd, Cr, $\mathrm{Pb}, \mathrm{Ni}, \mathrm{Co}$ ) in water from the earthen and concrete ponds (Mean $\pm \mathrm{SD})$.

\begin{tabular}{lccc}
\hline Parameters & \multicolumn{2}{c}{ Fish ponds } \\
\cline { 2 - 4 } & Concrete & Earthen & Permissible levels \\
Temperature $\left({ }^{\circ} \mathrm{C}\right)$ & $26 \pm 0.01$ & $29 \pm 0.05$ & $20-30$ \\
$\mathrm{pH}$ & $6.70 \pm 0.02$ & $6.76 \pm 0.06$ & $6.5-8.5$ \\
$\mathrm{TDS}(\mathrm{mg} / \mathrm{L})$ & $483 \pm 0.06$ & $56.66 \pm 0.03$ & 1000 \\
Conductivity( $\mathrm{ss} / \mathrm{cm})$ & $980 \pm 0.07$ & $123 \pm 0.06$ & $20-1000$ \\
$\mathrm{Hardness}$ & 23.31 & 22.17 & \\
$\mathrm{As}(\mathrm{mg} / \mathrm{L})$ & $0005 \pm 0,007$ & $0.007 \pm 0,009$ & - \\
$\mathrm{Cd}(\mathrm{mg} / \mathrm{L})$ & $0.049 \pm 0,08$ & $0.015 \pm 0,02$ & 0,01 \\
$\mathrm{Co}(\mathrm{mg} / \mathrm{L})$ & $0.0004 \pm 0.0001$ & $0.0003 \pm 0.0001$ & - \\
$\mathrm{Cr}(\mathrm{mg} / \mathrm{L})$ & $0.0003 \pm 0.0004$ & $0.004 \pm 0.0007$ & 0.05 \\
$\mathrm{~Pb}(\mathrm{mg} / \mathrm{L})$ & $0.0001 \pm 0.0003$ & $0.001 \pm 0.0001$ & 0.05 \\
$\mathrm{Ni}(\mathrm{mg} / \mathrm{L})$ & $0.0001 \pm 0.0004$ & $0.004 \pm 0.005$ & 0.02 \\
\hline
\end{tabular}

The physicochemical parameters and level of trace elements in pond water were compared with international standards. According to Madu et al. (2017), water quality parameters influence the heavy metals levels in freshwater bodies and their accumulation in aquatic biota. The findings of the study revealed that the mean temperatures for both earthen $\left(29.5^{\circ} \mathrm{C}\right)$ and concrete $\left(26^{\circ} \mathrm{C}\right)$ ponds were within the WHO recommended limits. Fish is a cold blooded animal, its temperature is dependent on the temperature of its environment. It changes with the temperature of the surroundings. The optimum water temperature for fish survival has been reported to be between $20-30^{\circ} \mathrm{C}$ (Bhatnagar and Devi 2013; Ntenegwe and Edema 2008). The temperature changes affect both the metabolism and physiology of fishes, and so its productivity (Agbaire et al. 2015). It was also observed that there is no significant difference in temperature in the culturing facilities used for the experiment. The reasons can be ascribe to the fact that the earthen and concrete facilities are subjected to the same light intensity and maybe the type of holding structure does not influence temperature change. The present results are in line with recent studies conducted by Moshood (2017) and Agbaire et al. (2015) which reported that the temperature of ponds ranges between $\left(30.9 \pm 0.1-29.4 \pm 0.1^{\circ} \mathrm{C}\right)$ and $\left(26.73 \pm 1.730^{\circ} \mathrm{C}\right)$ respectively. 
The $\mathrm{pH}$ measurement helps to determine if the water is a proper environment for fish, plants and algae (Olukunle et al. 2017). Fish are known to have an average pH of 7.4 therefore pond water average within this range is optimum. In the current study, the results obtained for $\mathrm{pH}$ were respectively in concrete ponds and earthen pond where within the limits. The desirable range for pond $\mathrm{pH}$ is $6.5-9.5$ and acceptable range is $5.5-10.0$ (Stone and Thomforde 2003). It has been reported that $\mathrm{pH}$ value between 6 and 9 was appropriate for fish production (Bhatnagar and Devi 2013). Thus, good pond productivity and fish health can be maintained. The findings are slightly lower than those obtained by Olukunle and Oyewumi (2017) in Akure (Nigeria) which reported a pH (7.10 \pm 0.06 - 8.39 \pm 0.01$)$ for concrete ponds and earthen ponds. A comparative study conducted by Moshood (2017) to assess the water quality of four types of aquaculture ponds under different culture systems reported $\mathrm{pH}$ values of $7.88 \pm 0.2$ for earthen and $6.75 \pm 0.2$ for concrete.

The conductivity values of the ponds gave a good estimate of the condition of ponds under the different culture systems. Both TDS and electrical conductivity are usually positively correlated. The earthen pond has a lower conductivity value of $123 \mathrm{~ms} / \mathrm{cm}$, and lower value of TDS than concrete ponds. The FAO acceptable limit for conductivity in aquaculture is between 20 and $1500 \mu \mathrm{s} / \mathrm{cm}$ (DWAF. 1996). The conductivity and total dissolved solids in earthen and concrete ponds probably came from the source of water for the ponds, absence of phytoplankton and aquatic vegetation to assimilate the mineral salts and the effects of residual feed in water which on decomposition added some mineral salts into the water. The presence of algae and macrophytes which utilized the salts and rainwater as source of water might be the reason for the slightly lower concentrations of conductivity and TDS in both earthen and natural ponds. The conductivity and TDS range however in the ponds were ideal for fish culture. Fish farmers generally use artificial animal feeds (pellets) to supplement pond nutrients in the study area (Bouelet Ntsama et al. 2018), previous authors (Ehigbonare and Ogunrinde 2010; Delince 1992; Ogbeibu and Edutie 2006) have also reported it to increase total dissolved solids in fish pond.

When compared with recommended limits, all the parameters were within the prescribed water quality standards for fish farming. Furthermore, there was no significant difference $(P<0.05)$ obtained among the parameters, except for TDS and conductivity showing the effects of the different culture systems. All these results in the present study compare reasonably well with other results obtained ( Olukunle and Oyewui 2017) . Water quality describes physical, chemical, biological and aesthetic properties of water which determine its fitness for use and its ability to maintain the health of farmed aquatic organisms. It is imperative to have all the physical, chemical and biological factors in the ponds in a balanced proportion and tolerable limit for optimum fish production.

\section{Concentrations of toxic metal in water}

Table 2 shows the concentration of trace element ( $\mathrm{As}, \mathrm{Cd}, \mathrm{Cr}, \mathrm{Pb}, \mathrm{Ni}, \mathrm{Co}$ ) in water from the earthen and concrete ponds. Heavy metal concentrations decreased in concrete ponds water in the sequence $\mathrm{Cd}>$ As $>\mathrm{Co}>\mathrm{Ni}>\mathrm{Cr}>\mathrm{Pb}$. For earthen ponds, the concentrations decreased as $\mathrm{Cd}>\mathrm{Co}>\mathrm{As}>\mathrm{Ni}>\mathrm{Cr}>\mathrm{Pb}$. $\mathrm{The}$ analysis of heavy metals in water showed that the concentrations did not exceed WHO guidelines. The 
concentrations of each trace element in water did not vary significantly either in concrete or earthen ponds. Comparatively the values obtained were lower than other studies in same type of fish ponds carried out by Echor and Okaliwe (2017) that reported As (1.36-1.30 $\mu \mathrm{g} / \mathrm{L}), \mathrm{Cr}(0.72-0.90 \mu \mathrm{g} / \mathrm{L})$ and $\mathrm{Pb}$ (2.00-1.60 $\mu \mathrm{g} / \mathrm{L})$. Aladasanmi et al. (2014) also reported high values above optimal levels for $\mathrm{Pb}$ (3.30 $\mu \mathrm{g} / \mathrm{L}), \operatorname{Cr}(9.11 \mu \mathrm{g} / \mathrm{L}), \operatorname{Co}(10.53 \mu \mathrm{g} / \mathrm{L})$ and $\mathrm{Ni}(90.22 \mu \mathrm{g} / \mathrm{L})$. Fish performs all their body functions in water therefore the quality of water is very important, the type of ponds influenced the water quality and the absorption of heavy metals in the tissue of fishes, in the present study no significant differences occurs concerning the contamination by heavy metals. Thilza and Muhammad (2010) reported that concrete ponds pose lesser threat to the livehood of the fish as compared to the earthen pond types. This is due to the management practices on fish farms; the constant change of water in concrete pond type increases the chances of heavy metals to be absorbed in the tissues of fishes causing health threat to both fish and fish consumers. Water is the first source of contamination for fish, since all production materials move into the water, the food they consume, their waste products such as faeces and therefore the origin of water should be control, in the present study water comes mainly from borehole for concrete ponds and for earthen ponds from rivers (Bouelet Ntsama et al. 2018). Fish can be affected by contaminants present in these different sources. However, there should be periodic or constant water quality control of fish ponds in order to ensure fish consumer's safety. The knowledge of heavy metal concentrations in water is very important with respect to management, human consumption of these aquaculture products and to determine the useful monitor and remediation of the most polluted area (Pravin et al. 2011). The concentrations of heavy metals in concrete and earthen fish ponds were slightly higher than permissible limits for these metals. This underscores the need to periodically study our fish rearing environment.

\section{Heavy metal in farmed fishes and bioconcentration factor (BCF) of trace elements}

Trace metal concentrations of tested heavy metals (dry weight) found in Oreochromis niloticus species raised in concrete and earthen ponds have been presented in Figure 2. All the six tested metals i.e. cadmium (Cd), lead (Pb) and chromium ( $\mathrm{Cr}$ ), Arsenic (As), Nickel (Ni), Cobalt (Co) were present in samples collected from different sites. In the flesh of Nile tilapia (Oreochromis niloticus) samples, the following values were obtained as median concentration of trace element in concrete ponds, As $(1.45 \mu \mathrm{g} / \mathrm{g})$; Cd ( $0.155 \mu \mathrm{g} / \mathrm{g}) ; \mathrm{Pb}(0.32 \mu \mathrm{g} / \mathrm{g}) ; \mathrm{Co}(0.37 \mu \mathrm{g} / \mathrm{g}) ; \mathrm{Ni}(12.75 \mu \mathrm{g} / \mathrm{g}) ; \mathrm{Cr}(4.133 \mu \mathrm{g} / \mathrm{g})$. Heavy metal concentrations decreased in fish of concrete ponds with the sequence of $\mathrm{Ni}>\mathrm{Cr}>\mathrm{As}>\mathrm{Co}>\mathrm{Pb}>\mathrm{Cd}$. For earthen ponds the median concentrations are As $(1.39 \mu \mathrm{g} / \mathrm{g}) ; \mathrm{Cd}(0.150 \mu \mathrm{g} / \mathrm{g}) ; \mathrm{Co}(0.402 \mu \mathrm{g} / \mathrm{g}) ; \mathrm{Cr}(2.17 \mu \mathrm{g} / \mathrm{g}) ; \mathrm{Pb}(0.137$ $\mu \mathrm{g} / \mathrm{g}) ; \mathrm{Ni}(0.570 \mu \mathrm{g} / \mathrm{g})$. The concentrations decreased as $\mathrm{Cr}>\mathrm{As}>\mathrm{Ni}>\mathrm{Co}>\mathrm{Cd}>\mathrm{Pb}$.

Trace metal concentrations of tested heavy metals (dry weight) found in Clarias gariepinus species raised in concrete and earthen ponds have been presented in Figure 3.

In the flesh of African catfish (Clarias gariepinus) samples, the following values were obtained as median concentration of trace element in concrete ponds, As $(2,77 \mu \mathrm{g} / \mathrm{g}) ; \mathrm{Cd}(0.11 \mu \mathrm{g} / \mathrm{g}) ; \mathrm{Pb}(0.33$ $\mu \mathrm{g} / \mathrm{g})$; $\mathrm{Co}(0.24 \mu \mathrm{g} / \mathrm{g}) ; \mathrm{Ni}(0.47 \mu \mathrm{g} / \mathrm{g}) ; \mathrm{Cr}(4.55 \mu \mathrm{g} / \mathrm{g})$. Heavy metal concentrations decreased in water of concrete ponds the sequence of $\mathrm{Cr}>\mathrm{As}>\mathrm{Ni}>\mathrm{Pb}>\mathrm{Co}>\mathrm{Cd}$. For earthen ponds the median concentrations 


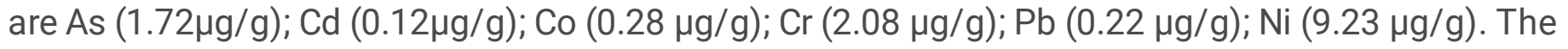
concentrations decreased as $\mathrm{Ni}>\mathrm{Cr}>\mathrm{As}>\mathrm{Co}>\mathrm{Pb}>\mathrm{Cd}$.

The present study revealed the presence of heavy metals in both rearing systems. This highlights the fact that pollution could affect concrete fish ponds as well. The results obtained suggest that the presence of heavy metals such as $\mathrm{As}, \mathrm{Cd}, \mathrm{Pb}, \mathrm{Cr}, \mathrm{Ni}, \mathrm{Co}$ and some of which are essential for life at trace levels are well above permissible concentrations making them a significant threat to ecosystems. Furthermore, toxic trace elements, arsenic, lead and cadmium were all present, in some cases at higher levels than acceptable concentrations. The levels of heavy metals concentrations in concrete fish ponds and earthen fish ponds were not significantly different when compared the two species except for $\mathrm{Ni}$ in Nile tilapia and cobalt for African catfish. Concentrations of Arsenic in the flesh of Nile tilapia and African catfish do not varies so. These values were above the maximum limits of FAO/WHO $(0.2 \mu \mathrm{g} / \mathrm{g})$. Cadmium concentrations in all fish samples were above the maximum limits set by the European commission (EC, 2006) of $0.05 \mathrm{mg} / \mathrm{kg}$. they were no significant differences at $\mathrm{p}<0.05$. For Lead, $\mathrm{Pb}$ content in all samples from earthen ponds was below the maximum limits $(0.3 \mathrm{mg} / \mathrm{kg})$, for concrete ponds the mean values slightly above the limit. The permissible limit for cobalt set by EU is $0.04 \mathrm{mg} / \mathrm{kg}$, Co concentrations obtained in the present study were above the limits. The values do not differ for each rearing system, concrete $(0.37 \mu \mathrm{g} / \mathrm{g})$ and earthen $(0.402 \mu \mathrm{g} / \mathrm{g})$ in the flesh of Nile tilapia but for African catfish these values varies significantly respectively concrete $(0.24 \mu \mathrm{g} / \mathrm{g})$ and earthen $(2.08 \mu \mathrm{g} / \mathrm{g})$. Ni Concentrations in all fish samples were significantly different for Nile tilapia, concrete $(12.75 \mu \mathrm{g} / \mathrm{g})$ and earthen $(0.570$ $\mu \mathrm{g} / \mathrm{g}$ ). For African catfish, there was no difference regarding the contamination in concrete and earthen $(0.47 ; 0.22 \mu \mathrm{g} / \mathrm{g})$. The concentration obtained were all within the limits of $0.4 \mathrm{mg} / \mathrm{kg}$ set by the European commission and $1 \mathrm{mg} / \mathrm{kg}$ set by the USEPA (2000) except for Nile tilapia raised in concrete ponds. $\mathrm{Cr}$ concentrations were above the international limits $(1 \mu \mathrm{g} / \mathrm{g})$ for all the fish samples, for Nile tilapia when compare the two system concrete $(4.133 \mu \mathrm{g} / \mathrm{g})$ and earthen $(2.17 \mu \mathrm{g} / \mathrm{g})$ no differences was but for African catfish the difference was significant (concrete: $4.55 \mu \mathrm{g} / \mathrm{g}$, earthen: $9.23 \mu \mathrm{g} / \mathrm{g}$ ). The result obtained from this study was similar to the findings of Daniel and Mathew (2016) and Taweel et al (2013). Madu et al (2017) reported higher values compares to this study, for instance Pb $(23.20 \mu \mathrm{g} / \mathrm{g})$ and $\mathrm{Ni}(17.55 \mu \mathrm{g} / \mathrm{g})$, these values were above the permissible values. These variations may be attributed to the differences between the localities, and the amount and source of pollution from an area to another, ecological needs, metabolism and feeding patterns of fish, and also the season in which studies were carried out in this study. Trace metals found commonly in fish are attributed to water, sediment or fish feed contaminated by the raw ingredients and by a mineral pack added by the manufacturer. In the current study, the presence of trace elements in fish were related to pond water, fertilizers and animal droppings use frequently in the study area (Bouelet Ntsama et al. 2018) and probably to fish feed, some authors reported the contamination of raw materials use to produce the feed ( $D$ as et al. 2017). The source of chromium in this research may have originated primarily from the feeds Cadmium is released to the environment in wastewater, and diffuse pollution is caused by contamination from fertilizers and local air pollution. The potential hazards of metals transferred to humans are probably dependent on the amount of fish consumed by an individual. 
The bioconcentration factor of each studied metal was evaluated for muscle tissues of $C$. gariepinus, $O$. niloticus (Table 5). The trend of the bioconcentration factors was similar to the trend of the metals in the tissues of the fish. In addition, the bioconcentration factor of $\mathrm{Mn}$ in the gill and liver of the three fish was significantly different $(p<0.05)$. Among the fish, BCF values recorded for tissues were higher than those recorded for the tissues of $H$. niloticus and $C$. gariepinus. The overall highest BCF was recorded for $\mathrm{Ni}$ $(67.99 \pm 9.58)$ and the overall lowest BCF was recorded for $\mathrm{Mn}(8.79 \pm 1.59)$ in the muscle of $H$. niloticus. In H. niloticus, the BCF of $\mathrm{Pb}$ was highest in all tissues studied, whereas in $C$. gariepinus, $\mathrm{Pb}$ had the highest $\mathrm{BCF}$ in the gills and muscle and $\mathrm{Ni}$ had the highest in the liver.

Table 3: Bioconcentration factor (BCF) values of heavy metals in muscle tissues of two fish species raised in concrete and earthen ponds.

\begin{tabular}{llllllll}
\hline Fish species & Pond type & As & Cd & Co & Cr & Pb & Ni \\
\hline C.gariepinus & Concrete & 435.8 & 3.08 & 525 & 240.6 & 2000 & 5600 \\
& Earthen & 311.28 & 10.06 & 700 & 180.5 & 200 & 140 \\
\multirow{2}{*}{ O.niloticus } & Concrete & 276 & 3.14 & 800 & 106.66 & 3400 & 7700 \\
& Earthen & 197.14 & 10.26 & 1066.66 & 80 & 340 & 192.5 \\
\hline
\end{tabular}

Bioconcentration factors of trace elements give a measure of the metal concentration in an organism relative to its concentration in the medium (Ajima et al. 2015). The BCF of heavy metals in muscle of the fish species in the present study showed that there was appreciable bioaccumulation of the various heavy metals in the fish tissues. Because all BCF values determined for the two fish species studied were above 100, according to USEPA (1991) there is no risk to human health associated with consumption of the flesh of these fish. The results of this study are consistent with the report by Abdallah and Nweeze et al., (2008) in which pelagic fish (herbivores) recorded higher metal concentrations than benthic (carnivorous) fish. Khalid argued that since species such as tilapia are herbivores, they bioaccumulate a higher metal concentration in the flesh than carnivorous catfish. This suggestion is in agreement with the current study, the catfish being generally more contaminated than tilapia. This may be due to dietary habits of carnivorous fish observed during dissection, a low tendency for sequestration (higher BCF) of trace metals and a greater susceptibility of this species to the presence of trace metals pollutants relative to in Tilapia.

\section{Relationships between trace element levels in fishes}

Inter-metal correlations of fish species were assessed and presented in Table 3 and 4 for both species. The correlations between the different metals may result from the similar accumulation behavior of the metals in the fishes and their interactions. Noted significant correlations among metals may reflect a common source of occurrence and indicative of similar biogeochemical pathways for subsequent accumulation in the muscle tissue of fishes. In the present study, significant correlation was observed between studied some heavy metals, in Nile tilapia correlations were between Lead and Nickel, Lead and Arsenic, Nickel and cobalt. In African Catfish, correlations were less strong between Cadmium and Nickel, 
Chromium and Nickel, Lead and Nickel, Cobalt and lead. Correlation matrixes were used to understand the significant differences between selected heavy metals in fish. Higher correlations between metals may reveal similar contamination levels and primarily originate from a similar source and be transported together (Yi et al. 2011; Maanan et al. 2014). Metals with highly positive correlations are believed to have similar sources, while those with highly negative correlations are believed to have different origins (AlAlimi and Alhudify 2016).

Table 4: Pearson's moment correlation coefficients between the heavy metals in Nile tilapia (Oreochromis niloticus)

\begin{tabular}{lllllll}
\hline & $\mathrm{Cd}$ & $\mathrm{Cr}$ & $\mathrm{Pb}$ & $\mathrm{Ni}$ & $\mathrm{As}$ & $\mathrm{Co}$ \\
\hline $\mathrm{Cd}$ & 0.000 & 0.434 & 0.467 & 0.136 & 0.453 & 0.280 \\
$\mathrm{Cr}$ & & 0.000 & 0.306 & 0.729 & 0.595 & 0.764 \\
$\mathrm{~Pb}$ & & & 0.000 & 0.968 & 0.870 & 0.195 \\
$\mathrm{Ni}$ & & & & 0.000 & 0.330 & 0.917 \\
$\mathrm{As}$ & & & & & 0.000 & 0.260 \\
$\mathrm{Co}$ & & & & & & 0.000 \\
\hline
\end{tabular}

Table 5: Pearson's moment correlation coefficients between the heavy metals African catfish (Clarias gariepinus)

\begin{tabular}{cllllll}
\hline & $\mathrm{Cd}$ & $\mathrm{Cr}$ & $\mathrm{Pb}$ & $\mathrm{Ni}$ & $\mathrm{As}$ & $\mathrm{Co}$ \\
\hline $\mathrm{Cd}$ & 0.000 & 0.475 & 0.421 & 0.841 & 0.687 & 0.167 \\
$\mathrm{Cr}$ & & 0.000 & 0.531 & 0.848 & 0.516 & 0.727 \\
$\mathrm{~Pb}$ & & & 0.000 & 0.811 & 0.283 & 0.814 \\
$\mathrm{Ni}$ & & & & 0.000 & 0.296 & 0.330 \\
$\mathrm{As}$ & & & & & 0.000 & 0.754 \\
$\mathrm{Co}$ & & & & & & 0.000 \\
\hline
\end{tabular}

\section{Health risk assessment}

The mean concentrations of heavy metals in the muscle of the two fish species were used to evaluate the human health risk from fish consumption. The average concentration of each metal in the muscle tissues of the fish was converted from dry weight to wet weight, in order to evaluate the health risk (Table 6). The $\mathrm{EDI}$ of $\mathrm{Ni}$ was highest in all fish species (8.76 for concrete pond in $C$. gariepinus and 6.34 for earthen ponds) followed by that of $\mathrm{Cr}$ (3.13 in 0 . niloticus for earthen ponds). The target hazard quotient of As was highest in all fish species (for $C$.gariepinus 6.36 in concrete ponds and 3.96 for earthen ponds; For 0 . niloticus, 3.33 in concrete ponds and 3.32 for earthen ponds), all these values were above 1 . The target hazard quotient of $\mathrm{Pb}$ was lowest in both species and rearing systems.

The THQ for most metals was less than 1 , which indicates that consumers may experience minor health effects by these metals consumption, except for As. Arsenic had THQ values between 3.32 to 6.76 for species and fish ponds. Hazard indices calculated for five metals $(\mathrm{Pb}, \mathrm{Cd}, \mathrm{Cr}$, and $\mathrm{Ni}$ ) in samples from both specie were all below 1 , indicative of a non-carcinogenic effect on human health for all the four metals. This means that the exposure of these metals to the human population from the consumption of 
farm - raised will not result in any considerable health risks that may be associated with the metals. The accumulation of metals in fish depends on equilibrium between absorption and depuration rates, and thus may reflect localized bioavailability of these substances. It also has to do with the concentration of the trace metal in the surrounding water as well as the feeding habits of the fish species. The adverse effects of heavy metals on aquatic and human lives are well known. Fish lose sense of smell in polluted water and consequently this affects their feeding ability (Brian 2013). In humans, acute or chronic exposure to heavy metals can lead to various disorders such as cancer and can also result in excessive damage due to oxidative stress induced by free radical formation (Monisha et al. 2014).

Table 6: Health risks assessment for individual metal by the determination of target hazard quotients (THQ) for fish species.

\begin{tabular}{lcccccccc}
\hline Fish species & Metal & $\begin{array}{c}\text { Concrete } \\
(\mu \mathrm{g} / \mathrm{g})\end{array}$ & EDI & THQ & Earthen $(\boldsymbol{\mu g} / \mathrm{g})$ & EDI & THQ & (RfD) \\
\hline C. gariepinus & $\mathrm{Cd}$ & 0.11 & 0.07 & 0.15 & 0.12 & 0.08 & 0.16 & 0.0005 \\
& $\mathrm{Cr}$ & 4.55 & 3.13 & 0.62 & 2.088 & 1.43 & 0.28 & 0.005 \\
& $\mathrm{~Pb}$ & 0.33 & 0.23 & 0.01 & 0.228 & 0.15 & 0.01 & 0.14 \\
& $\mathrm{Ni}$ & 12.75 & 8.76 & 0.43 & 9.23 & 6.34 & 0.31 & 0.02 \\
& $\mathrm{As}$ & 2.77 & 1.91 & 6.36 & 1.729 & 1.18 & 3.96 & 0.0003 \\
& $\mathrm{Co}$ & 0.24 & 0.16 & 0.55 & 0.28 & 0.19 & 0.64 & 0.0003 \\
& & & & & & & & \\
O. niloticus & $\mathrm{Cd}$ & 0.15 & 0.1 & 0.21 & 0.145 & 0.09 & 0.19 & 0.0005 \\
& $\mathrm{Cr}$ & 4.13 & 2.84 & 0.56 & 0.6941 & 0.48 & 0.09 & 0.005 \\
\hline
\end{tabular}

\section{Conclusion}

The present investigation reveals that all the physicochemical parameters and heavy metals except for cadmium in surveyed fish ponds were within the recommended limits for good fish production. The concentration in the fish flesh was slightly above the maximum limits and all the hazard quotient were below 1, except for Arsenic. There were no significant differences between concrete and earthen ponds. Thus, fish farming in the different regions of Cameroon investigated demands regular monitoring of physico-chemical parameters and metals status for effective management. Fish therefore, fish farmers should possess basic water quality kits to regularly monitor basic water quality parameters of their ponds. Principles of Hazard Analysis of Critical Control Point (HACCP) should be strictly adhered to in fish farm site location and production processes, so that our aquaculture product can go to the international market. The use of vascular plants that possess abilities to absorb these metals via their roots in ponds contaminated with pollutants can help to remedy such environment. Government should put in place a regulatory body which will control aquaculture production and ensure that licensed fish farmers are in line with the international norms.

\section{Abbreviations}

EDI: Estimated daily intake; THQ: Target hazard quotient;

\section{Declarations}


Acknowledgements

We are grateful to the staff of URAFPA, laboratory at University of Lorraine France Center for the laboratory assistance. We also wish to acknowledge the field work support of all the fish farmers.

\section{Funding}

No funding

\section{Availability of data and materials}

The data sets on which the conclusions of the paper rely is presented in the main body of the manuscript.

\section{Authors' contributions}

GM and GK conceived and designed the study. IS conducted the study. BA, CF, GP, JJ and HC contributed to the analysis and interpretation of data. IS drafted the manuscript. JS, GM and GK revised the draft manuscript. All authors read and approved the final manuscript.

\section{Competing interests}

The authors declare that they have no competing interests.

\section{Consent for publication}

Not applicable.

\section{Ethics approval and consent to participate}

Not applicable.

\section{References}

Al-Alimi AKAA, Alhudify NS (2016). Assessment of heavy metals contamination and its ecological risk in the surface sediments of Al- Mukalla coast, Yemen. J Sci Eng Res.; 3:13-23.

Anderson P.D. and Wiener J.B. Eating Fish. In: Graham, J.D. and Wiener, J.B., Eds., (1995) Risk versus Risk: Tradeoffs in Protecting Health and the Environment, Harvard University Press, Cambridge.

Bhatnagar A. and Devi P( 2013) Water Quality Guidance for the Management of Pond Fish Culture. intl J. Environ. Sci.; 3 (6) 1980 - 1993.

Boyd C.E (1990) Water Quality in Ponds for Aquaculture. Birmingham, Alabama, Birmingham Publishing Company.; 482pp. 
Brian B (2013) Fish Lose Sense of Smell in Polluted Waters. Environmental Health News. Available at www.environmentalhealthnews.org/ehs. Accessed on 15/5/13.

Buras N. (1993) Microbial safety of products from waste water fed aquaculture In: Pullin R.V.C, Rosenthal H. Maclean J.L; editors Environmental and Aquaculture in Developing Countries. Proceedings of the 31st International Centre for Living Aquatic Resources Management (ICLARM) Conference, Manila, Philippines.

Burger, J., Gaines, K.F., Boring, C.S., Stephens, W.L., Snodgrass, J., Dixon, C., McMahon, M., Shukla, S., Shukla, T., Gochfeld, M. (2002) Metal levels in fish from the Savannah River: Potential hazards to fish and other receptors, Environmental Research.. 89: 85-97.

Canli, m., Ay, O. and Kalay, M. Levels of heavy metals (Cd, Pd, Cu and Ni) in Christopher L.

Delgado,Nikolas Wada, Mark W. Rosegrant, Siet Meijer, and Mahfuzuddin Ahmed FISH TO 2020 Supply and Demand in Changing Global Markets International Food Policy Research Institute Washington, D.C. WorldFish Center Penang, Malaysia WorldFish Center Technical Report 62

Daniel I. E. and Matthew N. U (2016) Human Risk Assessment of Consuming Farm Raised Fish in Uyo, Nigeria JALSI, 9(2): 1-10, Article no.JALSI.29795. Journal of Applied Life Sciences International.; 9(2): 110.

Das PR, Hossain MK, Sarker BS, Parvin A, Das SS (2017) Heavy Metals in Farm Sediments, Feeds and Bioaccumulation of Some Selected Fish Aqua.; J 8: 218.

Daviglus M, Sheeshka, J. and Murkin, E (2002) Health Benefits from Eating Fifr. Comments on Toxicology. ; 8, 345-374. http://dx.doi.org/10.1080/08865140215064

Degrande A, Franzel S, Yeptiep SY, Asaah E, Tsobeng A, Tchoundjeu Z (2012) The effects of fish pond types on the physical and chemical water quality and its implications on fish health in maiduguri metropolis, Nigeria Effectiveness of grassroots organizations in the dissemination of agroforestry innovations. Yaounde, Cameroon: World Agroforestry Centre. ; West and Central Africa.

Delince G (1992) The Ecology of Fish and Ecosystem with Special Reference to Africa, Kluwer. Academic Publishers, Dordrecht, Netherland.; 23.

Dirilgen, $N$ (2001) Accumulation of heavy metals in freshwater organisms: Assessment of toxic interactions. Turkish Journal of Chemistry.;25(3): 173 - 179. DOI: 10.5897/AJB09.995 ISSN 1684-5315 (C)2010 Academic Journals

Echor Felix Okaliwe (2017) Comparative Assessment of the Concentration of Heavy Metals in Concrete and Earthen Fish Ponds in South - East, Nigeria. The International Journal Of Science \& Technoledge.; ISSN 2321 - 919X 
Edwards, Paula Kay (2010) "The Correlation of the Concentration of Selected Metals Determined in Water and Fish Samples from a Public Pond." (Electronic Theses and Dissertations. Paper; 1774. http://dc.etsu.edu/etd/1774

Ehigbonare J. E. and Ogunrinde Y. O. (2010) Physicochemical Analysis of Fish Pond Water in Okada and its Environs, Nigeria. Afri. J. of Biotechn.; 9 (36): 5922 - 5928.

EPA (U.S. Environmental Protection Agency). (2006) A Framework for Assessing Health Risks of Environmental Exposures to Children. EPA/600/R-05/093F. National Center for Environmental Assessment, Office of Research and Development, U.S. Environmental Protection Agency,. Washington, DC. September 2006 [online]. Available: http://cfpub.epa.gov/ncea/cfm/recordisplay.cfm?deid=158363

FAO. (2011) Global Aquaculture Production

FAO/WHO (2011) Joint FAO/WHO food standards programme codex committee on contaminants in foods.,fifth. session pp 64-89.

Ibrahim AThA, Omar HM.. (2013) Seasonal variation of heavy metals accumulation in muscles of the African catfish Clarias gariepinus and in River Nile water and sediments at Assiut governorate, Egypt. J Biol Earth Sci .; 3:B236-B248.

E. Ehiagbonare and Y. O. Ogunrinde (2010) Physico-chemical analysis of fish pond water in Okada and its environs, Nigeria African Journal of Biotechnology.; Vol. 9(36), pp. 5922-5928, 6 September, Available online at http://www.academicjournals.org/AJB

Knuth B, Connelly N.A, Sheeshka J and Patterson J.. (2003) Weighing Health Benefits and Health Risk Information When Consuming Sport-Caught Fian. Risk Analysis. 23, 1185-1197.

http://dx.doi.org/10.1111/j.0272-4332.2003.00392.x

Stancheva Lubomir Makedonski Elitsa Petrova Petrova-Pavlova (2013) Determination of heavy metals ( $\mathrm{Pb}, \mathrm{Cd}, \mathrm{As}$ and $\mathrm{Hg}$ ) in Black Sea grey mullet (Mugil cephalus)Bulgarian Journal of Agricultural Science.; 19:30-34.

Maanan M, Saddik M, Maanan M, Chaibi M, Assobhei O, Zourarah B (2014) Environmental and ecological risk assessment of heavy metals in sediments of Nador lagoon, Morocco. Ecol Indic.; 48:616-626.

Maule AG, Gannam AL, Davis JW (2007) Chemical contaminants in fish feeds used in federal salmonid hatcheries in the USA. Chemosphere:;67:1308-1315.

MINADER (2009) Zones agroécologiques. Chambre d'Agriculture de l'Ouest Cameroun, informations géographiques et économiques.; Available at http://chagriouestcamer.afrikblog.com/archives/2009/03/30/13194779.html 
Monisha Jaishankar, Tenzin Tseten, Naresh Anbalagan, Blessy B. Mathew, and Krishnannurthy N.Beeregowda. (2014) Toxicity, Mechanism and Health Effects of Some Heavy metals. Interdisciplinary Toxicology:;7(2): 60-72.

Moshood Keke Mustapha (2017). Comparative Assessment of the Water Quality of Four Types of Aquaculture Ponds under Different Culture Systems advanced research in life sciences 1(1), , 104-110 DOI: $10.1515 /$ arls-2017-0017.

Ntenegwe, F. N. and Edema M. O (2008) Physicochemical and Microbiological Characteristics of water of fish production using small Ponds, Phy and Chem Earth.; 33: 701 - 707.

Ogbeibu A. E. and Edutie C. (2006) Effect of Brewery Effluent on the Water Quality and Rotifers of Ikpoba River, Southern Nigeria. . Ecoserve Publishers 1 - 17.

Ogbeibu, A.E. and P.U. Ezevara, (2002) Impact of brewery effluents on the Ikpoba River, using the fish communities as bio-indicators. Journal of Aquatic Research.; 17: 35-44.

Olowosegun, O.M., T. Olowosegun and H. Mohammed (2005) A review on the effect of water pollution on fish and the fishing industry of Nigeria. In 2005 FISON Conference Proceedings .2005; 14-18 Nov Port Harcourt, Nigeria pp: 423-428.

Olukunle O. F, Oyewumi O. O ( 2017 ) Physicochemical Properties of Two Fish Ponds in Akure, Implications for Artificial Fish Culture International Journal of Environment, Agriculture and Biotechnology (IJEAB) Vol-2, Issue -2, http://dx.doi.org/10.22161/ijeab/2.2.54

Osman AGM, Kloas W (2010). Water quality and heavy metal monitoring in water, sediments, and tissues of the African catfish Clarias gariepinus (Burchell, 1822) from the River Nile, Egypt. J Environ Prot.;1:389400 .

Pravin U, Kalpanau M, and Lokhande S (2011) Impact Assessment of Pollution on some lake water located at and around Thane City of Maharashtra, India: physico-chemical properties and toxic effects of heavy metal content. Interdisciplinary Environmental Review.; 12(3): 215.

Ruxton CH, Reed SC, Simpson MJ, Millington KJ (2004). The health benefits of omega-3 polyunsaturated fatty acids: a review of the evidence. J Hum Nutr Diet . 17:449-459.

Stone N.M, Thomforde H.K (2004). Understanding Your Fish Pond Water Analysis Report. Cooperative Extension Program, University of Arkansas at Pine Bluff Aquaculture / Fisheries.. 4pp.

Summerfelt R.C (2000) Water Quality Considerations for Aquaculture. Department of Animal Ecology.; lowa State University, Ames, USA. 8pp.

Susanta Nath and Madhumita Bhoumik (2013) Levels of toxic metals in edible fish from a wetland of India International Journal of Environmental Sciences.; Volume 3 No.5. 
Thilza I.B. And Muhammad T (2010) The Effects of Management Practices On The Physical And Chemical Water Qualities And Its Possible Implications On Fish Health In Maiduguri Metropolis. Researcher.;2(11):15-23. (ISSN: 1553-9865). http://www.sciencepub.net

Tiimub, Benjamin Makimilua( 2013) Determination of Selected Heavy Metals and Iron Concentration in Two common Fish Species in Densu River at Weija District in Grater Accra Region of Ghana American International Journal of Biology.; 1(1); July pp. 45-55

VanLoon GW, Duffy SJ (2000) Environmental Chemistry: A global perspective. Oxford: Oxford University Press.Ward NI.. Trace elements. In: Fifield FW, Haines PJ. (eds), Environmental analytical chemistry. Oxford: Blackwell Science. 2011. pp. 360-392.

VUTUKURU S. S (2005) Acute effects of hexavalent chromium on survival, oxygen consumption, haematological parameters and some biochemical profiles of the Indian Major carp, Labe rohita. International Journal of Environmental Research and Public Health.; 2(3): 456 - 462.

Wim, V, Issabelle S, Karen, Stefan, D. H, John, V. C. (2007) Consumer perception versus scientific evidence of farmed and wild fish: exploratory insights for Belgium. Aquaculture International.; 15: 121-136.

Yi Y, Yang Z, Zhang S (2011) Ecological risk assessment of heavy metals in sediment and human health risk assessment of heavy metals in fishes in the middle and lower reaches of the Yangtze River basin. Environ Pollut.;159:2575-2585.

Zaza, S, de Balogh K., Palmery, M., Pastorelli, A.A., Stacchini, P (2015) Human exposure in Italy to lead, cadmium and mercury through fish and seafood product consumption from Eastern Central Atlantic Fishing Area. Journal of Food Composition and Analysis.; 40: 148-153.

Zheng N, Wang Q, Zhang X, Zheng D, Zhang Z, Zhang S (2007) Population health risk due to dietary intake of heavy metals in the industrial area of Huludao City, China. Sci Total Environ .;387:96-104.

\section{Figures}




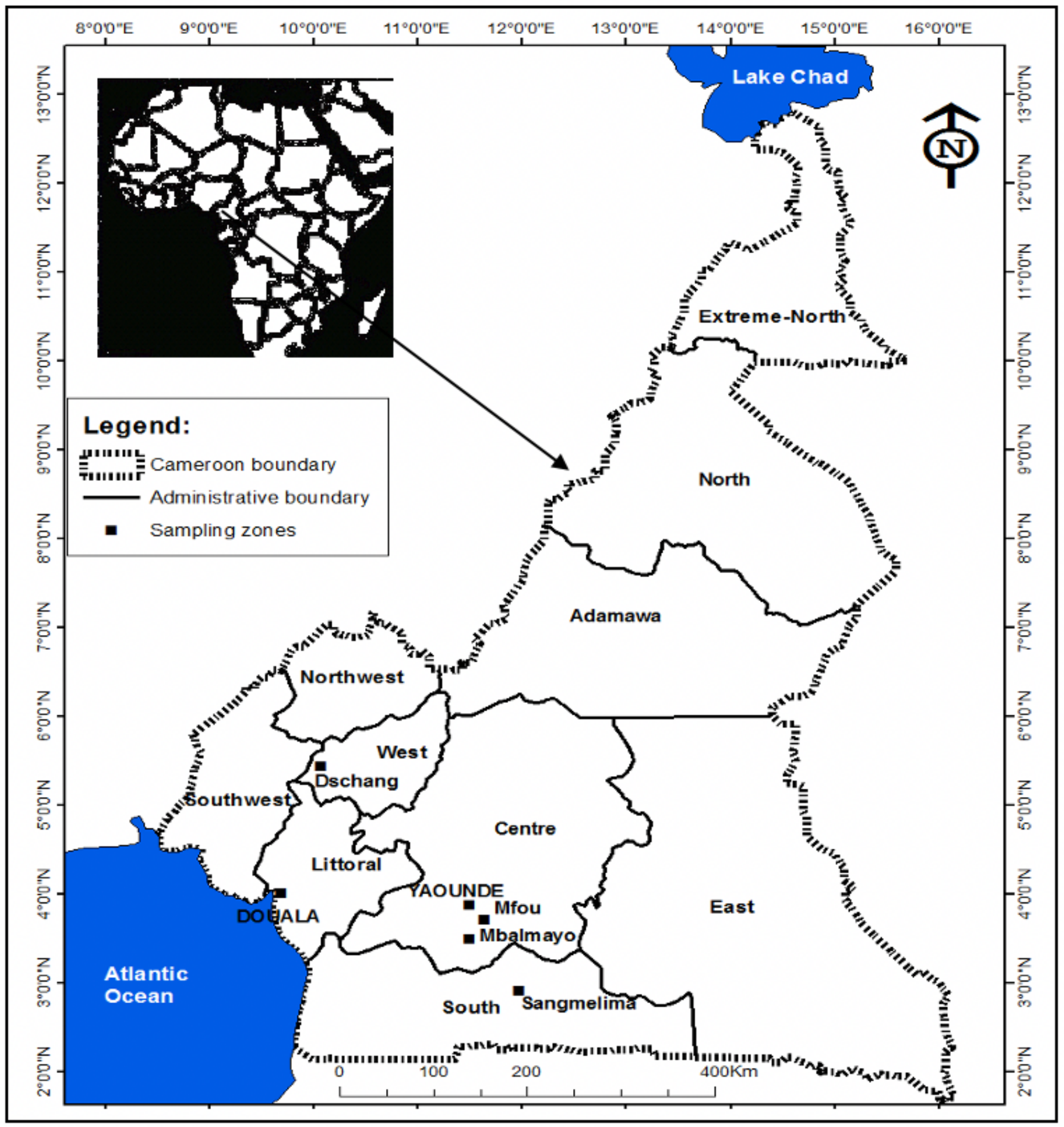

Figure 1

Sampling zones 
Cd

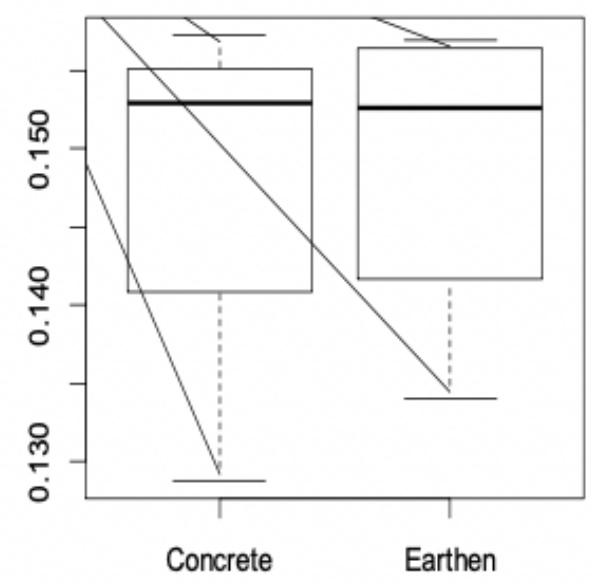

KW: NS

$\mathrm{Ni}$

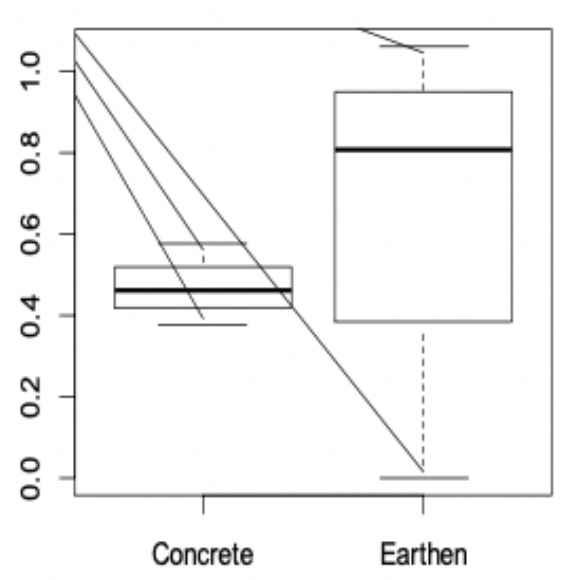

KW: *

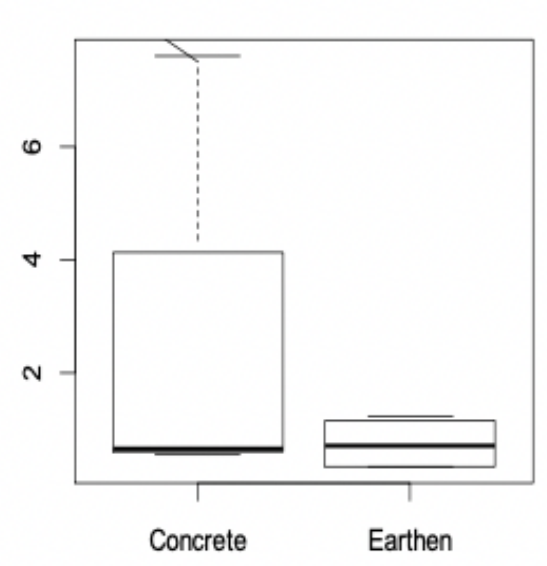

KW: NS

As

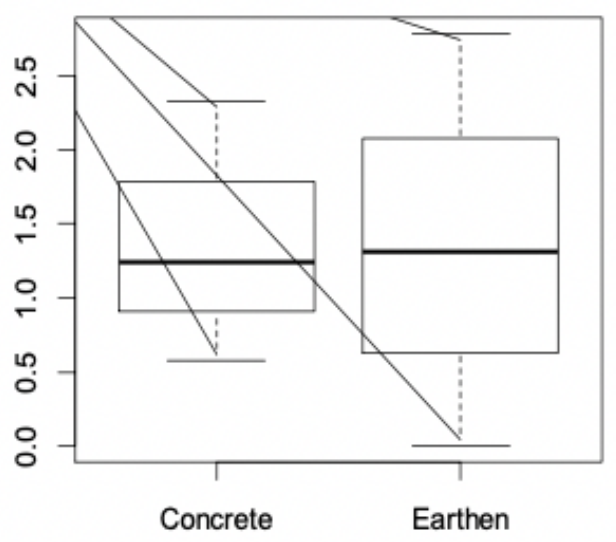

KW: NS

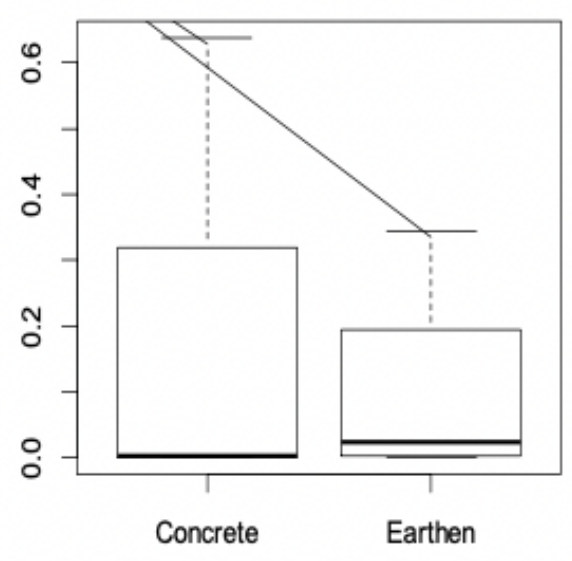

KW: NS

Co

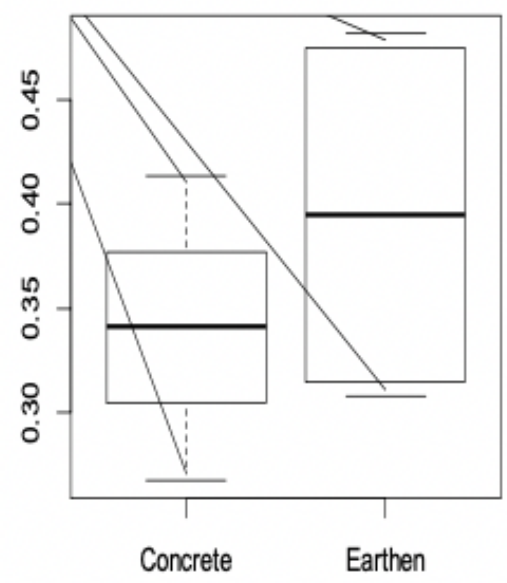

KW: *

Figure 2

Comparison of Trace metal concentrations ( $\mu \mathrm{g} . \mathrm{g}-1$ d.w.) in flesh of Nile tilapia (Oreochromis niloticus) reared in concrete and earthen. For each species, the significances of the level differences between both rearing systems are indicated below the boxplots. KW: Kruskal Wallis test; NS: Non significative. 


\section{Cd}

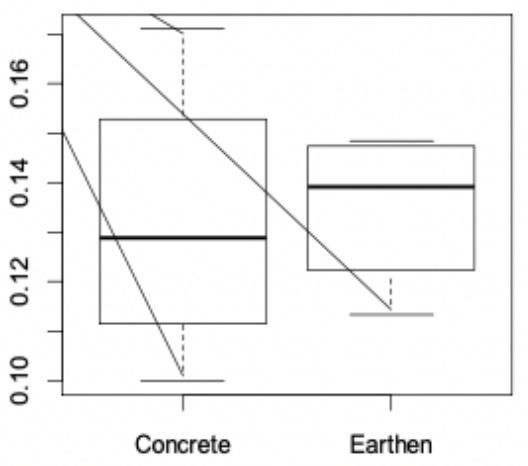

KW: NS

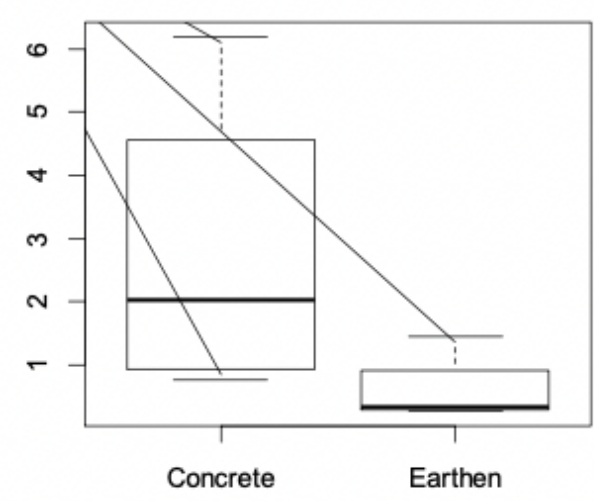

KW: NS
$\mathbf{C r}$

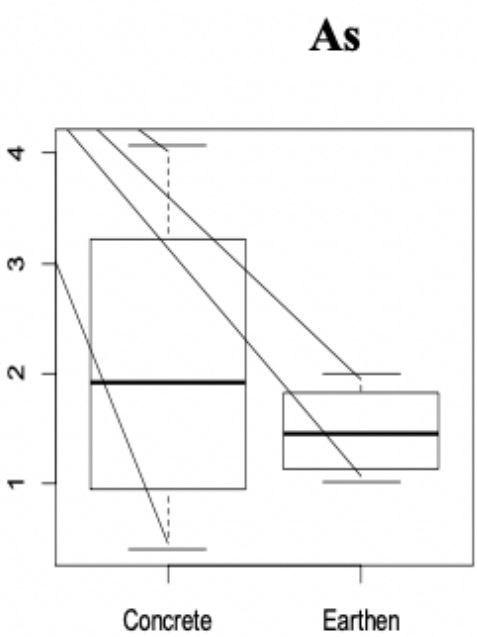

KW: NS
$\mathbf{P b}$

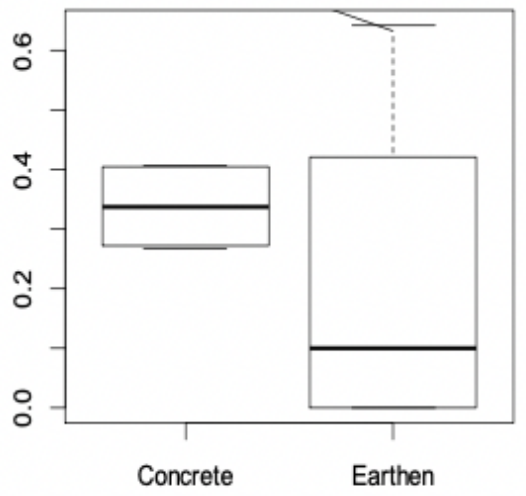

KW: NS

\section{Co}

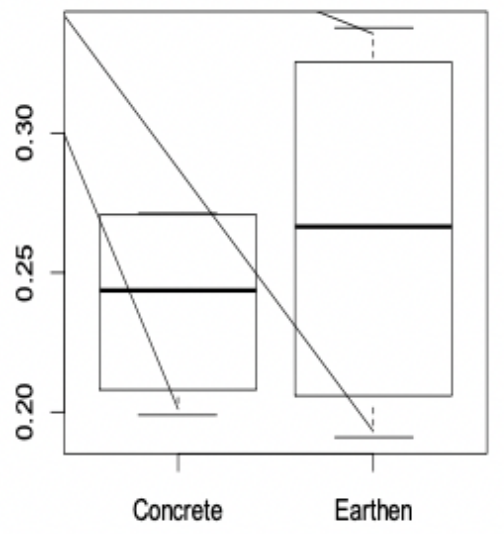

KW: NS

\section{Figure 3}

Comparison of Trace metal concentrations ( $\mu \mathrm{g} . \mathrm{g}-1 \mathrm{~d}$.w.) in flesh of African catfish (Clarias gariepinus) reared in concrete and earthen. For each species, the significances of the level differences between both rearing systems are indicated below the boxplots. KW: Kruskal Wallis test; NS: Non Significative. 